\title{
KAJIAN KINETIKA KATALITIK HERBAL DARI AIR HASIL REMASAN DAUN KEMBANG SEPATU DALAM MENURUNKAN PANAS DALAM
}

\author{
Dewi Handayani \\ Jurusan Kimia, FMIPA, Universitas Negeri Padang, Indonesia
}

E-mail: dewhdyn18@gmail.com

\begin{abstract}
Abstrak. Studi ini bertujuan untuk membuat air hasil remasan daun kembang sepatu yang dapat menurunkan panas dalam. Metode yang dilakukan adalah eksperimen dan uji aktivitas katalitik secara langsung. Tahapan pertama dilakukan dengan pembuatan air hasil remasan dari daun kembang sepatu. Uji aktifitas katalitik langsung dilakukan dengan variasi selama dua hari. Hasil eksperimen membuktikan bahwa air hasil remasan daun kembang sepatu dapat menurunkan panas dalam. Keadaan optimum dalam air hasil remasan ini tercapai pada jangka pemakaian 4 jam setelah dikonsumsi. Penyembuhan ini diduga karena aktivitas katalitik air hasil remasan daun kembang sepatu cepat bekerja pada pusat panas dalam. Hal ini karena daun kembang sepatu mengandung senyawa yang dapat menurunkan panas dalam yaitu glikosida.
\end{abstract}

Kata Kunci : Remasan, Daun, kembang sepatu, Panas dalam, Glikosida, Katalis, Herbal.

\section{Pendahuluan}

Reaksi kimia sering dijumpai dalam kehidupan sehari - hari. Dalam reaksi kimia akan dapat ditemukan oleh manusia [1-4]. Reaksi kimia dapat kita jumpai di semua objek kehidupan. Dalam tubuh manusia juga terdapat reaksi kimia yang setiap hari membantu dalam aktivitas manusia, seperti pada organ tubuh manusia [5-10]. Melalui pengamatan, reaksi kimia dapat dibuktikan dengan adanya produk yang dihasilkan.. Produk - produk yang sudah dihasilkan dari reaksi kimia tentunya akan memiliki permasalahan 
tersendiri [11-13]. Dengan adanya reaksi kimia masalah tersebut dapat dipecahkan [14-15]. Dengan kata lain reaksi kimia sangat penting, jika tanpa reaksi kimia maka kehidupan manusia tidak akan berjalan dengan baik, dengan berjalannya waktu tanpa reaksi kimia kehidupan akan punah[16-22].

Reaksi kimia terjadi oleh dua buah zat yang bereaksi dengan hasil nya berupa produk dari kedua buah zat yang sudah bereaksi tersebut [23-26]. Produk yang sudah dihasilkan biasanya belum berupa hasil yang diharapkan, sebab banyak hal dapat menjelaskan hal ini [27-34]. Salah satunya zat yang beraksi sudah tidak sesuai standarisasi zat yang dibutuhkan, dan ada pula penghambat lainnya ialah kontak langsung dengan udara sehingga akan mempengaruhi suhu dan tekanan [35-41].

Reaksi kimia umumnya memiliki ciri - ciri, selain adanya pereaksi dan dihasilkan produk, reaksi ini juga memiliki penghambat dan suatu peluang keuntungan dalam reaksi, seperti yang dijelasakan sebelumnya [42-47]. Penghambat ini ada karena kondisi suatu reaksi yang tidak sesuai pada lingkungan tempat terjadinya reaksi [48-52]. Ada reaksi yang membutuhkan kondisi sangat panas untuk mengaktifkan zat pereaksi dan juga ada reaksi yang sulit pada kondisi terlalu beku atau memiliki suhu minus [53-59]. Selain penghambat reaksi kimia juga memiliki peluang keutungan seperti dalam kehidupan sehari - hari dalam menyembuhkan suatu penyakit [60-62]. Reaksi kimia yang ini disebabkan oleh adanya suatu katalis [63-68].

Umumnya reaksi kimia memiliki kelangsungan kecepatan dalam membentuk hasil reaksi, ada yang langsung bereaksi namun ada pula yang tidak berjalan sesuai dengan yang diharapkan [69-72]. Tentu hal ini memiliki hubungan penyelesaian yaitu dengan katalis [73-77]. Katalis sering dijadikan sebagai bahan percobaan karena pengaruh yang sangat besar pada suatu reaksi kimia [78-83]. Hal ini bisa terjadi karena ciri - ciri katalis ini tidak ikut bereaksi namun berpengaruh pada reaksi kimia [84-88].

Katalis ada karena pengamatan oleh manusia yang menginginkan sesuatu yang tidak boleh terjadi [89-93]. Kembali mengemukakan katalis merupakan sesuatu yang akan mempercepat suatu yang sedang berlangsung 
[94-96]. Spesifik katalis ini dapat digunakan dalam skala kecil hingga skala yang besar [97-100]. Katalis tidak berperan secara langsung (spesifik) namun keberadaanya sangat diharapkan dan dibutuhkan demi mewujudkan suatu reaksi yang sempurna [101-103].

Hal-hal yang menjadi kriteria katalis sangat lah mudah, karena katalis yang digunakan tidak perlu banyak karena katalis ini hanya sebagai pemercepat reaksi[104-106]. Katalis harus disesuaikan dengan suasana lingkungan tempat reaksi ini terjadi. Salah satunya katalis herbal yang akan menjadi pembahasan dalam kajian ini. Katalis herbal adalah sesuatu yang bersifat alami [107-109].

Berdasarkan dugaan ternyata daun kembang sepatu ini memiliki kandungan anti panas dalam yang tentunya dapat menurunkan pamas dalam. Banyak orang yang sudah mencoba mengkaji penemuan ini. Daun kembang sepatu ini sangat mudah ditemukan diberbagai daerah, karena tanaman nya sangat mudah di tanam [110-112]. Ditinjau dari kondisi fisik pohon kembang sepatu ini memiliki ketinggian sekitar 1,5 meter. Tanaman kembang sepatu ini memiliki bunga yang bervariasi dengan berbagai warna [113-115]. Serta daun yang diduga paling banyak mengandung khasiat. Serta bagian akar tanaman kembang sepatu ini juga sering dijadikan sebagai ramuan herbal oleh manusia [116-118].

Berdasarkan informasi turun temurun dari orang - orang tua di kota padang ini bahwa daun kembang sepatu bisa dijadikan sebagai herbal dalam menurunkan panas dalam. Untuk membuktikan dugaan tersebut dapat dilakukan eksperimen bahwa, apakah air hasil remasan daun kembang sepatu ini dapat menurunkan panas dalam yang menjadi tujuan dari eksperimen ini [119-120].

\section{Metode}

2.1 Alat dan bahan

Peralatan yang dipakai yaitu magic Com (Cosmos) sebagai wadah daun kembang sepatu serta saringan (Stainless stell) untuk menyaring air hasil 
remasan daun kembang sepatu. Bahan yang digunakan adalah daun kembang sepatu yang diambil di daerah Air Tawar Barat di Padang sekitar kampus Universitas Negeri Padang, serta adapula air (Aqua).

2.2 Prosedur kerja

\subsubsection{Penyiapan sampel}

Sampel yang diambil dari lokasi Jalan Gajah 4 arah kampus Universitas Negeri Padang

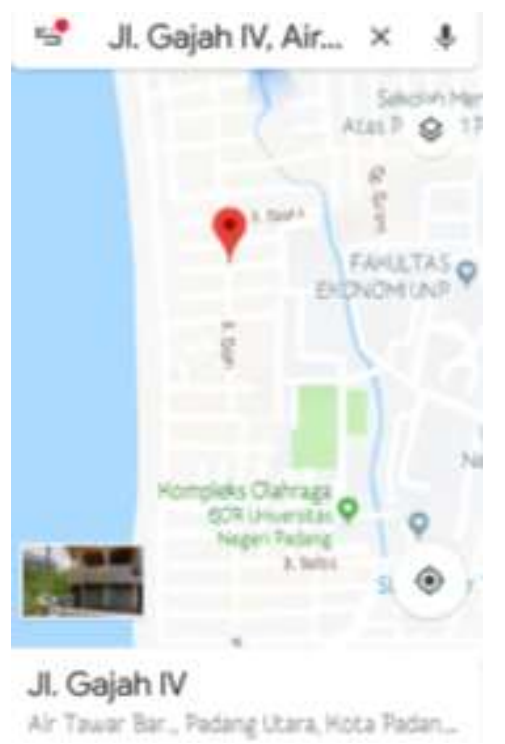

Sampel diambil sebanyak 30 lembar daun Sampel yang digunakan dsn dicuci menggunakan air.

\subsubsection{Pembuatan ekstrak}

Air hasil remasan ini dibuat dengan meremas daun kembang sepatu dengan perlahan, dengan menambahkan air sedikit demi sedikit, hingga daun mengeluarkan hasilnya. Air yang digunakan adalah 100 $\mathrm{mL}$.

\subsubsection{Pengujian ekstrak}

Air hasil remasan daun kembang sepatu ini akan di berikan kepada orang yang sedang mengalami panas dalam dengan variasi yang sama dalam jangka waktu tertentu.

Metode ini dapat dibuat dengan diagram alir dibawah ini : 


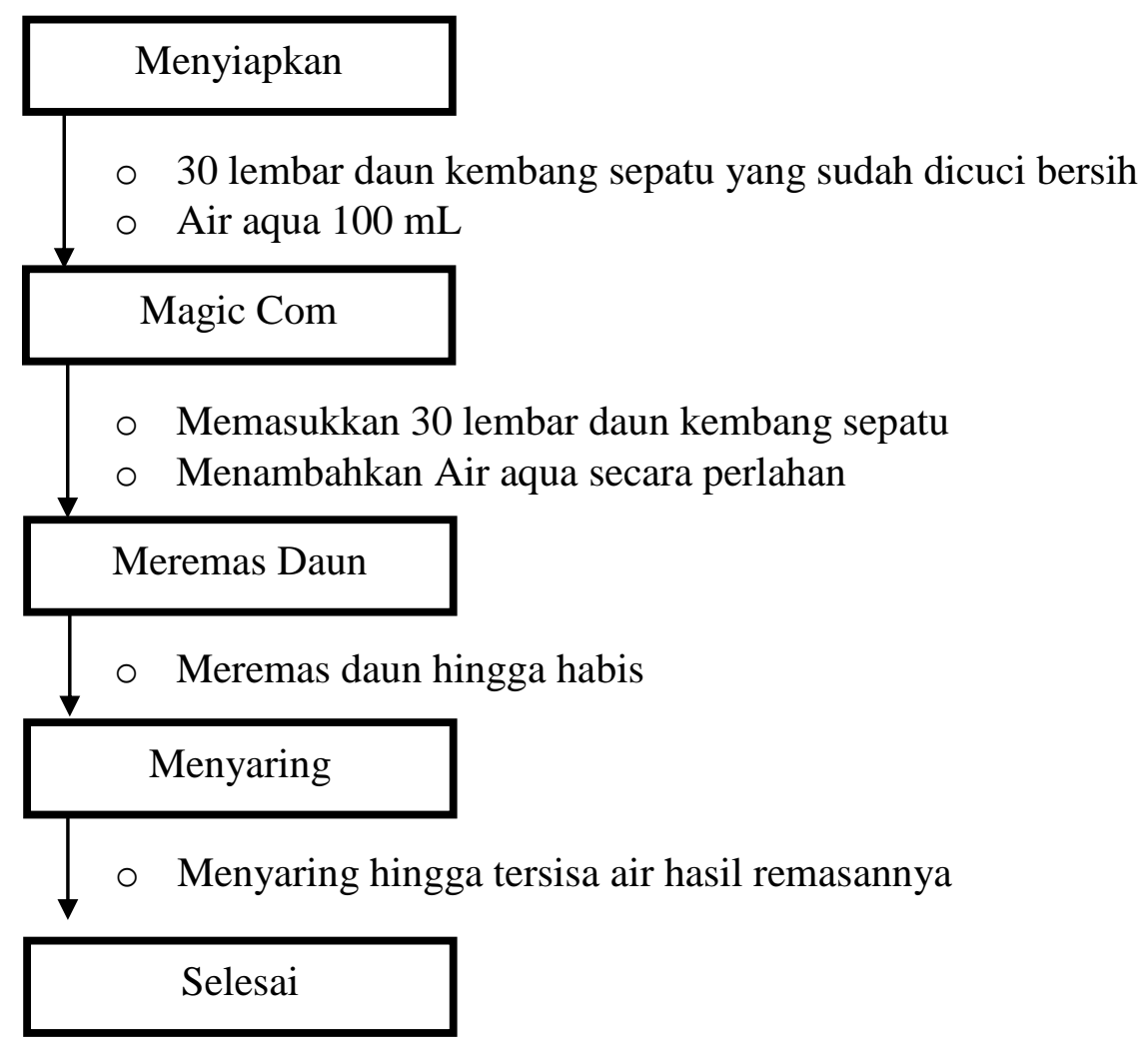

\section{Hasil}

3.1 Hasil dari pembuatan air hasil remasan daun kembang sepatu dihasilkan sebanyak $50 \mathrm{~mL}$ dari 30 lembar daun kembang sepatu dan $100 \mathrm{~mL}$ air. Air remasan yang dihasilkan akan berwarna hijau dan sedikit kental.

Hal ini dapat ditunjukkan dari gambar berikut ini :

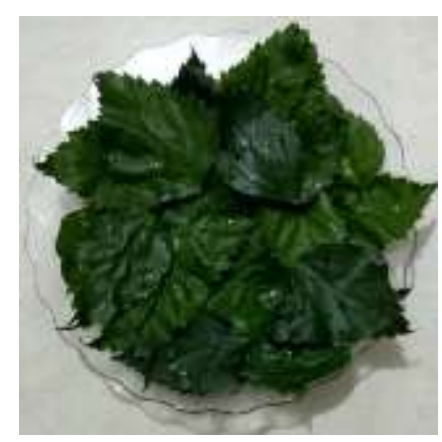

Gambar 1. Daun kembang sepatu 


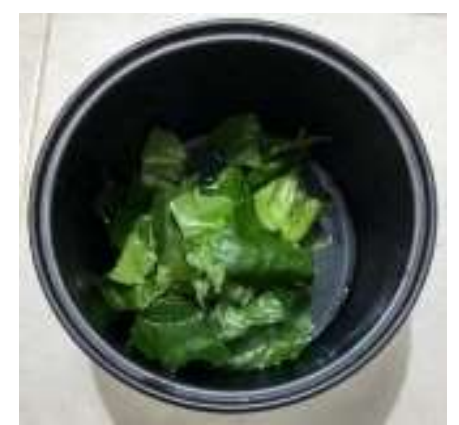

Gambar 2. Daun kembang sepatu ditambah air

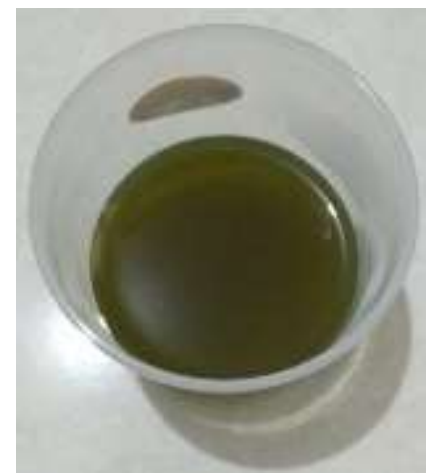

Gambar 3. Air hasil remasan Daun kembang sepatu

3.2 Hasil dari pengujian terhadap orang ternyata berhasil dalam menurunkan panas dalam

TABEL HASIL PENGAMATAN DARI PENDERITA PANAS DALAM

\begin{tabular}{|c|c|c|c|}
\hline NO. & PERLAKUAN & WAKTU & HASIL \\
\hline 1. & \multirow{4}{*}{$\begin{array}{c}50 \text { mL air hasil remasan } \\
\text { di berikan kepada orang } \\
\text { yang sedang panas } \\
\text { dalam }\end{array}$} & 1 jam & $* * * *$ \\
\hline 2. & & $2 \mathrm{jam}$ & $* * *$ \\
\hline 3. & & 3 jam & $* *$ \\
\hline 4. & & 4 jam & $*$ \\
\hline
\end{tabular}

\section{Pembahasan}

4.1 Pembuatan

Pada eksperimen ini bertujuan untuk membuktikan bahwa daun kembang sepatu memiliki kandungan flavonoid yang dapat menurunkan panas dalam, yang dapat diambi dari daun kembang sepatu [121-123]. Pada saat melakukan pembuatan air hasil remasan daun kembang sepatu 
mengalami kendala yaitu dalam menentukan banyak air yang dipakai. Karena jika air yang digunakan terlalu banyak akan menghilangkan khasiat daun [124-126]. Daun yang diremas harus dipastikan sudah semua nya tercampur dengan air sehingga pada saat disaring bukan daun yang terbawa tetapi sari dari daun tersebut [127-128]. Alat yang digunakan juga sangat mempengaruhi dalam keberhasilan karena dapat menjadi penghambat atau merusak jaringan daun dari tanaman ini [129-130].

\subsection{Uji coba}

Pada saat mengujikan air hasil remasan daun kembang sepatu ini terjadi perkembangan yang signifikan. Penderita panas dalam ini merasakan tubuh yang lebih sehat setelah mengkonsumsi herbal ini [131132]. Pada kondisi ekstrem panas dalam sangat mudah menyerang siapapun, sebab panas dalam terjadi karena perubahan kondisi lingkungan. Pernyataan ini dapat dibuktikan dari pemaparan grafik berikut :

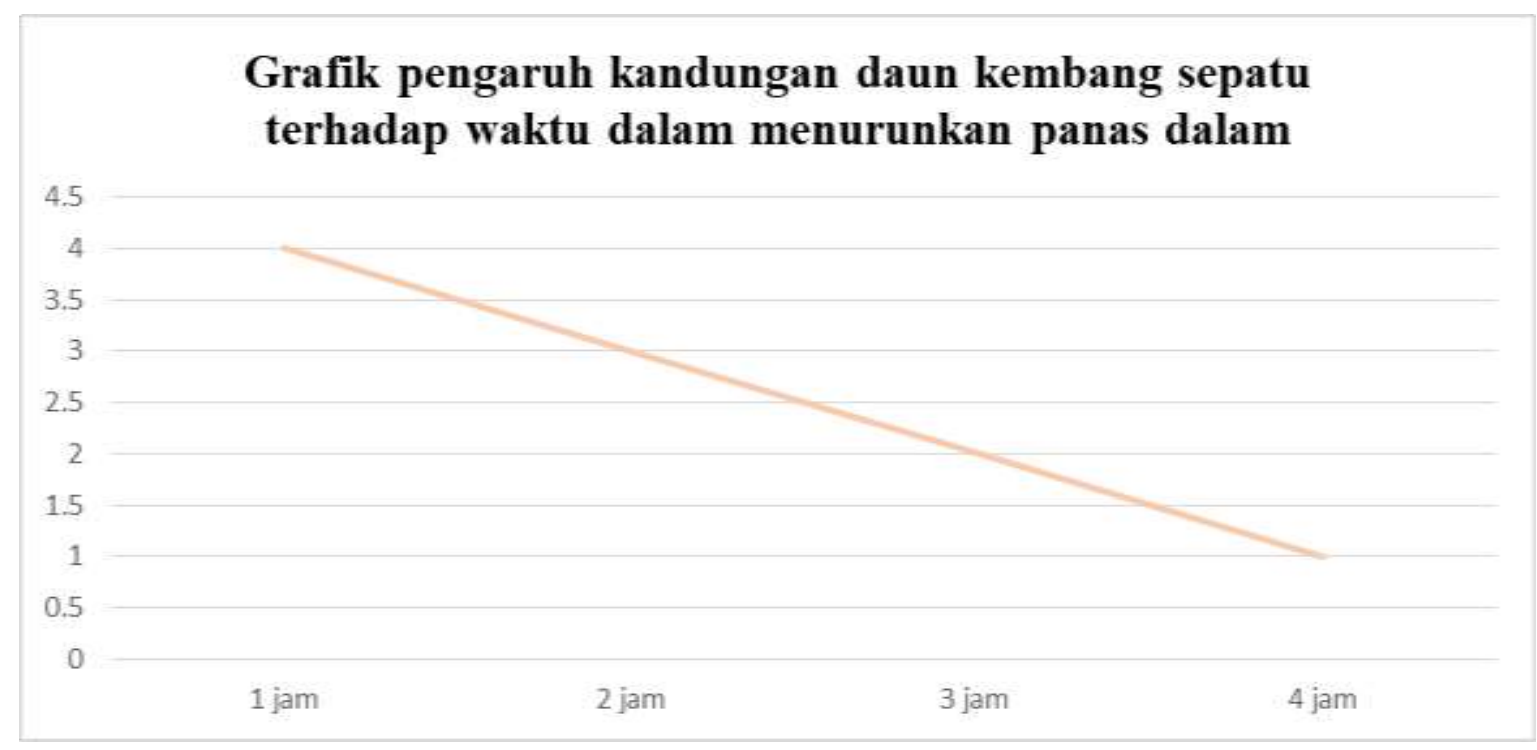

Pada grafik diatas terlihat bahwa garis kurva menurun itu karena panas dalam sudah menurun secara signifikan namun belum bias memberikan kesembuhan yang sebaiknya [133]. Karena daun kembang sepatu hanya menjadi katalis yang mampu mempercepat penyembuhan [134].

\subsection{Intereaksi}


Daun kembang sepatu dengan nama latin Hibiscus rosa-sinensis L. memiliki kandung glikosida.entunya daun kembang sepatu ini banyak sekali kandungan glikosida [135-136]. Kandungan daun kembang sepatu ini sudah familiar dalam bidang ilmu kimia. Setiap tanaman akan terdapat glikosida terutama pada daun tanaman kembang sepatu ini, namun kandungan glikosida nya tinggi. Glikosida juga memiliki kandungan yang cukup sedikit sebab glikosida sangat labil dalam reaksi kimia [137-138].
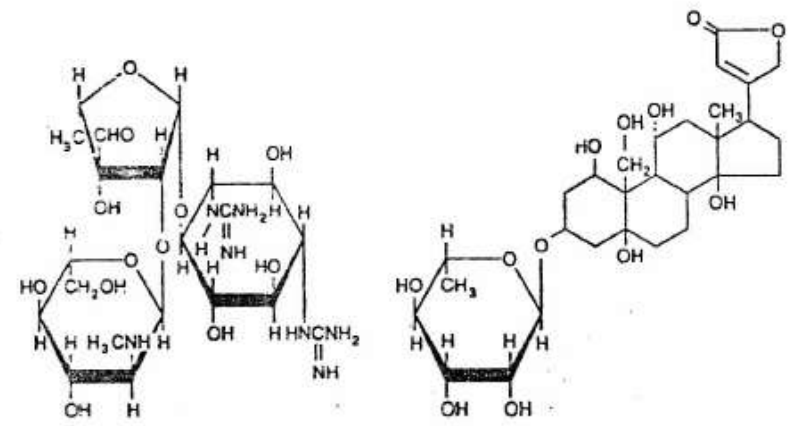

Glikosida dapat memperlambat reaksi jika penggunaan yang terlalu banyak, sebab mengandung toksik yang cukup tinggi. Terbukti bahwa daun kembang sepatu dapat menurunkan panas dalam sebab jika kandungan glikosida tinggi dapat membangkitkan efek bioaktif yang memiliki keuntungan [139-141]. Namun konsumsi air hasil remasan ini dalam batas yang masih dapat diterima oleh tubuh sehingga tidak menimbulkan efek baru [142-143]. Glikosida ini merupakan reaksi kimia yang memiliki kepolaran lebih tinggi sehingga pelarut air jauh dibawahnya [144-146]. Air hasil remasan ini cepat bekerja sama dengan baik pada sumber panas dalam. Pada glikosida ini senyawa hasil kondensasi asam karboksilat dan atom c pada monosakarida [147-149]. Senyawa glikosida sering terdapat pada tumbuhan adanya gugus hemiasetal [150].

\section{Kesimpulan}

Berdasarkan eksperimen yang telah diuji cobakan dapat disimpulkan bahwa :

1. Air hasil remasan daun kembang sepatu ini bisa dibuat dengan 30 lembar dan $100 \mathrm{~mL}$ air. 
2. Air hasil remasan daun kembang sepatu dapat menurunkan panas dalam , dengan sekali minum dalam jangka waktu 4 jam.

3. Air hasil remasan daun kembang sepatu memiliki kandungan glikosida ini sehingga berkhasiat dalam menurunkan panas dalam.

\section{Referensi}

[1] Altway, Ali, Winardi, Sugeng, Rachimoellah, M,2004.Aplikasi Packet Diffusion Model untuk Menganalisis Pengaruh Fenomena Micromixing terhadap Jalannya Reaksi Kimia Paralel di dalam Reaktor Tangki reraduk Kontinyu dengan Aliran Umpan Terpisah. Vol 28, No 2

[2] Wardhani, Ratih Pramita, Ningsih, Rini Rahayu, Ramadhona, Rika, Astuti, Hutari Puji, Fitriyani, Noor,2013. TEH BIJI SEMANGKA (CITRULLUS LANATUS) SEBAGAI OBAT HERBAL ALTERNATIF JANTUNG DAN ANTI KANKER. Vol. 4 No. 2

[3] S, Gunanati, Priosoeryanto, Bambang Pontjo, Wientarsih, Ietje, Sumarny, Ros,2009. Pengobatan penyakit tumor mammae melalaui operasi (matektomi dan ovariohisterektomi) dan kombinasinya (tanaman herbal) pada hewan. Vol 14, No 1

[4] Febriani, Amelia, Elya, Berna, Jufri, Mahdi, 2016. Uji Akvitas dan Keamanan Hair Tonic Ekstrak Daun Kembang Sepatu pada Pertumbuhan Rambut Kelinci. Vol 8, No 1

[5] Kairupan, Christy Priskila, 2014. UJI DAYA HAMBAT EKSTRAK ETANOL DAUN KEMBANG SEPATU (Hibiscus rosa-sinensis L) TERHADAP PERTUMBUHAN BAKTERI Escherichia coli. Vol 3, No 2

[6] Sanjaya, H. (2017) "DEGRADASI METHYLENE BLUE MENGGUNAKAN KATALIS ZnO-PEG DENGAN METODE FOTOSONOLISIS", EKSAKTA: Berkala Ilmiah Bidang MIPA, 18(02), pp. 21-29. doi: 10.24036/eksakta/vol18-iss02/45.

[7] Horiza, H., Azhar, M. and Efendi, J. (2017) "EKSTRAKSI DAN KARAKTERISASI INULIN DARI UMBI DAHLIA (Dahlia sp.L) SEGAR DAN DISIMPAN", EKSAKTA: Berkala Ilmiah Bidang MIPA, 18(01), pp. 31-39. doi: 10.24036/eksakta/vol18-iss01/14.

[8] Iskandar, I., Horiza, H. and Fauzi, N. (2017) "EFEKTIVITAS BUBUK BIJI PEPAYA (Carica Papaya Linnaeaus) SEBAGAI LARVASIDA ALAMI TERHADAP KEMATIAN LARVA AEDES AEGYPTY TAHUN 2015", EKSAKTA: Berkala Ilmiah Bidang MIPA, 18(01), pp. 12-18. doi: 10.24036/eksakta/vol18-iss01/12.

[9] Iryani, I., Iswendi, I. and Katrina, I. T. (2017) "UJI AKTIVITAS ANTI DIABETES MELLITUS SENYAWA METABOLIT SEKUNDER FRAKSI AIR DARI BERAS KETAN HITAM ( Oryza satival. Var glutinosa) PADA MENCIT PUTIH”, EKSAKTA: Berkala Ilmiah Bidang MIPA, 18(01), pp. 5460. doi: 10.24036/eksakta/vol18-iss01/17.

[10] Chatri, M., Mansyurdin, M., Bakhtiar, A. and Adnadi, P. (2017) "PERBANDINGAN KOMPONEN MINYAK ATSIRI ANTARA DAUN MUDA DAN DAUN DEWASA PADA HYPTIS SUAVEOLENS 
(L.)POIT”, EKSAKTA: Berkala Ilmiah Bidang MIPA, 18(02), pp. 1-12. doi: 10.24036/eksakta/vol18-iss02/41.

[11] Parbuntari, H., Prestica, Y., Gunawan, R., Nurman, M. and Adella, F. (2018) "Preliminary Phytochemical Screening (Qualitative Analysis) of Cacao Leaves (Theobroma cacao L.)", EKSAKTA: Berkala Ilmiah Bidang MIPA, 19(2), pp. 40-45. doi: 10.24036/eksakta/vol19-iss2/142.

[11] Dinata, M. and Soehardi, F. (2018) "Factor Analysis of Physics Chemistry Waters that Affects Damage Safety Cliff on the Outskirts of River Siak", EKSAKTA: Berkala Ilmiah Bidang MIPA, 19(2), pp. 46-49. doi: 10.24036/eksakta/vol19-iss2/143.

[12] Rizki Saputra, M. and Sumarmin, R. (2018) "PENGARUH EKSTRAK DAUN SIRIH MERAH (Piper crocatum Ruiz \& Pav.) TERHADAP GLUKOSA DARAH MENCIT (Mus musculus L.) JANTAN YANG DIINDUKSI SUKROSA", EKSAKTA: Berkala Ilmiah Bidang MIPA, 19(1), pp. 43-55. doi: 10.24036/eksakta/vol19-iss1/124.

[13] Tutuarima, T. (2017) "SIFAT FISIK DAN KIMIA MARMALADE JERUK KALAMANSI (Citrus microcarpa) : KAJIAN KONSENTRASI PEKTIN DAN SUKROSA Physical and Chemical Properties of Marmalade Citrus of Calamondin (Citrus microcarpa) : Study of Pectin and Sucrose Concentrations", EKSAKTA: Berkala Ilmiah Bidang MIPA, 18(02), pp. 164172. doi: 10.24036/eksakta/vol18-iss02/73.

[14] Suryelita S, Etika SB, Kurnia NS. ISOLASI DAN KARAKTERISASI SENYAWA STEROID DARI DAUN CEMARA NATAL (Cupressus funebris Endl.). EKSAKTA [Internet]. 5May2017 [cited 18Apr.2019];18(01):86-4. Available from: http://eksakta.ppj.unp.ac.id/index.php/eksakta/article/view/23

[15] Sari, A. (2017) "POTENSI ANTIOKSIDAN ALAMI PADA EKSTRAK DAUN JAMBLANG (Syzigium cumini (L.) Skeels)", EKSAKTA: Berkala Ilmiah Bidang MIPA, 18(02), pp. 107-112. doi: 10.24036/eksakta/vol18iss02/61.

[16] Susilaningrum, D. (2017) "PEMODELAN REGRESI LOGISTIK PADA FAKTOR YANG MEMPENGARUHI PHBS PADA RUMAH TANGGA PENDERITA TBC DI PESISIR SURABAYA”, EKSAKTA: Berkala Ilmiah Bidang MIPA, 18(02), pp. 121-128. doi: 10.24036/eksakta/vol18-iss02/65.

[17] Putri, D., Fifendy, M. and putri, M. (2018) "DIVERSITAS BAKTERI ENDOFIT PADA DAUN MUDA DAN TUA TUMBUHAN ANDALEH (Morus macroura miq.)", EKSAKTA: Berkala Ilmiah Bidang MIPA, 19(1), pp. 125-130. doi: 10.24036/eksakta/vol19-iss 1/122.

[18] Mulia, M. (2017) "ISOLASI KUMARIN DARI KULIT BUAH LIMAU SUNDAI (Citrus nobilis Lour)", EKSAKTA: Berkala Ilmiah Bidang MIPA, 18(02), pp. 137-145. doi: 10.24036/eksakta/vol18-iss02/70.

[19] Horiza, H. (2018) "The influence of the use of activated carbon Fibres of the cane Against the drop in Salinity In the well Dig In RT 003 RW 006 Village Cape Town Unggat Tanjungpinang Year 2017”, EKSAKTA: Berkala Ilmiah Bidang MIPA, 19(1), pp. 1-6. doi: 10.24036/eksakta/vol19-iss1/97.

[20] Abdullah, Jaya, Jaka Darma, Rodiansono,2010. Optimasi Jumlah Katalis $\mathrm{KOH}$ dan $\mathrm{NaOH}$ pada Pembuatan Biodiesel dari Minyak Kelapa Sawit Menggunakan Kopelarut. Vol 4, No 1 
[21] Mambang, D. Elysa Putri, Rosidah, -, Suryanto, Dwi,2014. AKTIVITAS ANTIBAKTERI EKSTRAK TEMPE TERHADAP BAKTERI Bacillus subtilis DAN Staphylococcus aureus [Antibacterial Activity of Tempe Extracts on Bacillus subtilis and Staphylococcus aureus]. Vol 25, No 1

[22] Irawan, RM. Bagus,2006. PENGARUH KATALIS TEMBAGA DAN KROM TERHADAP EMISI GAS CARBON MONOKSIDA DAN HIDRO CARBON PADA KENDARAAN MOTOR BENSIN.VOL 4,NO 1

[23] Marchaban, Sudibyo Martono, Mimiek Murrukmihadi, Subagus Wahyuono, 2014. ISOLASI DAN PENETAPAN KADAR ALKALOID DALAM EKSTRAK ETANOLIK, FRAKSI TIDAK LARUT ETIL ASETAT DAN FRAKSI HASIL VLC BUNGA KEMBANG SEPATU (Hibiscus rosasinensis L.). Vol 8 No 1

[24] Aisyah, Riandini, Gunawan, Ryan Budi, Sutrisna, EM, 2016. EFEK EKSTRAK ETANOL 70\% DAUN KEMBANG SEPATU (Hibiscus rosasinensis L.) DALAM MEMPERPENDEK WAKTU PERDARAHAN DAN WAKTU PEMBEKUAN PADA MENCIT JANTAN GALUR SWISS. Vol 8, No 1

[25] Harahap, Nuroni, Hasairin, Ashar, 2015. Analisis dan Pemanfaatan Bunga Kembang Sepatu (Hibiscus rosa-sinensis) Sebagai Zat Warna Alami Pada Makanan Cenil. Vol 1, No 3

[26] Zainul, R. (2018, August 16). Effect of Temperature and Particle Motion against the ability of $\mathrm{ZnO}$ Semiconductor Photocatalyst in Humic Acid. https://doi.org/10.31227/osf.io/wnygb

[27] Zainul, R. (2018, August 16). Design and Modification of Copper Oxide Electrodes for Improving Conversion Coefficient Indoors Lights (PV-Cell) Photocells. https://doi.org/10.31227/osf.io/pgn84

[28] Feronika, N. I., \& Zainul, R. (2018, November 19). Kalium Permanganat: Termodinamika Mengenai Transport Ionik dalam Air. https://doi.org/10.31227/osf.io/g6eyk

[29] Zainul, R. (2018, August 16). Determination of the half-life and the quantum yield of $\mathrm{ZnO}$ semiconductor photocatalyst in humic acid. https://doi.org/10.31227/osf.io/e8a9x

[30] Putri, D. F., Ritonga, H. M., Murdiati, V., \& Zainul, R. (2018, October 15). A REVIEW WHAT IS HYDROTHERMAL ?. https://doi.org/10.31227/osf.io/dm56c

[31] Lubis, A. P., \& Zainul, R. (2018, November 5). Interaksi Molekuler Amonium Hidroksida. https://doi.org/10.31227/osf.io/jht3b

[32] Liza, Y. M., Yasin, R. C., Maidani, S. S., \& Zainul, R. (2018, October 9). SOL GEL : PRINCIPLE AND TECHNIQUE (A REVIEW). https://doi.org/10.31227/osf.io/2cuh8

[33] Firdaus, A., \& Zainul, R. (2018, November 6). SESIUM KLORIDA (CsCl) : TRANSPORT ION DALAM LARUTAN. https://doi.org/10.31227/osf.io/rj6gy

[34] Zainul, R. (2018, August 16). Design and Modification of Copper Oxide Electrodes for Improving Conversion Coefficient Indoors Lights (PV-Cell) Photocells. https://doi.org/10.31227/osf.io/pgn84

[35] Guci, S. R. F., Zainul, R., \& Azhar, M. (2018, September 19). PENGEMBANGAN MEDIA PEMBELAJARAN BERBASIS TIGA LEVEL 
REPRESENTASI MENGGUNAKAN PREZI PADA MATERI KESETIMBANGAN KIMIA KELAS XI SMA/MA. https://doi.org/10.31227/osf.io/n7jkf

[36]Febriani, S. S., Yolanda, T., Arianti, V. A., \& Zainul, R. (2018, October 12). A Review Solid Stated : Principles and Methode. https://doi.org/10.31227/osf.io/7us4x

[37] Dinata, A. A., Rosyadi, A. M., Hamid, S., \& Zainul, R. (2018, October 15). A Review CHEMICAL VAPOR DEPOSITION : PROCESS AND APPLICATION. https://doi.org/10.31227/osf.io/yfeau

[38] Anhar, A., Sumarmin, R., \& Zainul, R. (2018, August 11). Measurement of Glycemic Index of West Sumatera Local Rice Genotypes for Healthy Food Selection. https://doi.org/10.31227/osf.io/tgy8h

[39] M, Sanjaya, H., \& Zainul, R. (2018, August 11). Characterization of napa soil and adsorption of $\mathrm{Pb}$ (II) from aqueous solutions using on column method. https://doi.org/10.31227/osf.io/t8fh9

[40] Hakimi, A., \& Zainul, R. (2019, January 31). Asam Arsenat (H3AsO4) : Analisis Molekular dan Karakteristik Senyawa. https://doi.org/10.31227/osf.io/e486z

[41] H., Sanjaya, H., \& Zainul, R. (2018, August 11). Synthesis and Electrical Properties of ZnO-ITO and Al-ITO thin Film by Spin Coating Technique Through Sol Gel Process. https://doi.org/10.31227/osf.io/unrt4

[42] Zainul, R., Alif, A., Aziz, H., Arief, S., \& s. (2018, August 16). Photoelectrosplitting Water Mechanism at Carbon Electrode Surface using Indoor lights. https://doi.org/10.31227/osf.io/vcxq8

[43] Zainul, R. (2018, June 18). OPTIMIZATION OF SPIRULINA PLANTESIS CULTURE FOR ANTIOXIDANT PRODUCTION. https://doi.org/10.17605/OSF.IO/FD6E4

[44] Husna, H., \& Zainul, R. (2019, February 3). A Review : Aspek Termodinamika LiNO3 dalam Larutannya. https://doi.org/10.31227/osf.io/45mbd

[45] Awalliyah, A., Ikhwan, H., Nugiasari, V., \& Zainul, R. (2018, October 15). A REVIEW PRINSIP DASAR MILLING DALAM SINTESIS MATERIAL. https://doi.org/10.17605/OSF.IO/JUAF5

[46] Zainul, R., Oktavia, B., Dewata, I., \& efendi, j. (2018, August 16). Studi Dinamika Molekular dan Kinetika Reaksi pada Pembelahan Molekul Air untuk Produksi Gas Hidrogen. https://doi.org/10.31227/osf.io/876s3

[47] Nurfadilah, K. K., \& Zainul, R. (2019, February 3). Kalium Nitrat (KNO3): Karakteristik Senyawa dan Transpor Ion. https://doi.org/10.31227/osf.io/dr8ef

[48] Shafitri, M., \& Zainul, R. (2019, February 3). Vanadium Pentaoksida (V2O5) : Termodinamika Molecular dan Interaksi Ion dalam Larutan. https://doi.org/10.31227/osf.io/jgmvd

[49] Zainul, R., Effendi, J., \& M. (2018, December 10). Phototransformation of Linear Alkylbenzene Sulphonate (LAS) Surfactant Using $\mathrm{ZnO}-\mathrm{CuO}$ Composite Photocatalyst. https://doi.org/10.31227/osf.io/fec28

[50] Febriani, S. S., Yolanda, T., Arianti, V. A., \& Zainul, R. (2018, October 12). A Review Solid Stated : Principles and Methode. https://doi.org/10.31227/osf.io/7us4x 
[51] M., Yani, S. R., \& Zainul, R. (2018, August 31). Aktivasi Tanah Napa dan Pengaruhnya Terhadap Adsorpsi Ion Timbal (II)/ $\mathrm{Pb} 2+$. https://doi.org/10.31227/osf.io/ps523

[52] Sari, E. S. J., \& Zainul, R. (2019, January 31). Nitrogen Triflorida (NF3) : Termodinamika dan Transpor Elektron NF3. https://doi.org/10.31227/osf.io/3nzrh

[53] Zainul, R., \& Prima, C. B. (2018, December 9). TEKNOLOGI MATERIAL MAJU Prinsip Dasar dan Aspek Rekayasa. https://doi.org/10.31227/osf.io/p63wc

[54] Alfionita, T., \& Zainul, R. (2019, January 29). Calcium Chloride ( $\mathrm{CaCl} 2)$ : Characteristics and Molecular Interaction in Solution. https://doi.org/10.31227/osf.io/m37xj

[55] Sari, M., \& Zainul, R. (2018, November 19). Kalium Dikromat (K2Cr2O7) Spektroskopi dan Transpor K2Cr2O7. https://doi.org/10.31227/osf.io/w92je

[56] Artika, P. I., \& Zainul, R. (2018, November 19). Potassium Bromide (KBr): Transformasi ionik dan sifat temodinamika dalam Larutan. https://doi.org/10.31227/osf.io/a5hyz

[57] Dwynda, I., \& Zainul, R. (2018, November 19). Boric Acid (H3 (BO3): Recognize The Molecular Interactions in Solutions. https://doi.org/10.31227/osf.io/6wead

[58] Yanti, C. F., \& Zainul, R. (2018, December 2). A Review Ba (OH)2 : Transpor Ionik pada Barium Hidroksida di dalam Air dengan Konsep Termodinamika. https://doi.org/10.31227/osf.io/fsbq3

[59] Y., \& Zainul, R. (2018, November 18). SILVER SULFATE (Ag2SO4): MOLECULAR ANALYSIS AND ION TRANSPORT. https://doi.org/10.31227/osf.io/n8g9k

[60] Zainul, R., \& Prima, C. B. (2018, November 11). Desain Geometri Sel PV. https://doi.org/10.31227/osf.io/7n8t4

[61] Yuliani, F., \& Zainul, R. (2018, November 13). Analisis Termodinamika Molekul Magnesium Sulphate (MgSO4). https://doi.org/10.31227/osf.io/uxz4y

[62] Delvi, I. P., \& Zainul, R. (2019, February 3). Mercury (II) Nitrate (Hg (NO3)2): Interaksi Molekul dan Adsorpsi $\mathrm{Hg}$ dengan Karbon Aktif. https://doi.org/10.31227/osf.io/eqyax

[63] Jumalia, R., \& Zainul, R. (2019, February 3). Natrium Karbonat : Termodinamika dan Transport Ion. https://doi.org/10.31227/osf.io/y2vq9

[64] Kristy, D. P., \& Zainul, R. (2019, February 3). Analisis Molekular dan Transpor Ion Natrium Silikat. https://doi.org/10.31227/osf.io/8ac4m

[65] Warlinda, Y. A., \& Zainul, R. (2019, January 29). Asam Posfat (H3PO4): Ionic Transformation of Phosphoric Acid in Aqueous Solution. https://doi.org/10.31227/osf.io/s3y8v

[66] Zainul, R. (2018, December 24). Prototype Reaktor Deksagonal. https://doi.org/10.31227/osf.io/d7wzk

[67] Zainul, R. and Wardani, S. (2019) "The Hydrogen Generator Performance of Sandwich Designed 4/4 Al-Cu Plates", EKSAKTA: Berkala Ilmiah Bidang MIPA, 20(1), pp. 100-104. doi: 10.24036/eksakta/vol20-iss1/177. 
[68] Ruswandi, R. (2018) "Determination of Fructose Content resulted by Inulin Hydrolysis with DNS as Oxidizer", EKSAKTA: Berkala Ilmiah Bidang MIPA, 19(1), pp. 14-23. doi: 10.24036/eksakta/vol19-iss1/102.

[69] Joebaedi, K. (2018) "MODEL STAR $(1 ; 1)$ PADA DATA PRODUKTIVITAS TEH", EKSAKTA: Berkala Ilmiah Bidang MIPA, 19(1), pp. 35-38. doi: 10.24036/eksakta/vol19-iss1/118.

[70] Hidayani, T. (2018) "GRAFTING POLIPROPILENA DENGAN MALEAT ANHIDRIDA SEBAGAI PENGIKAT SILANG DENGAN INISIATOR BENZOIL PEROKSIDA", EKSAKTA: Berkala Ilmiah Bidang MIPA, 19(1), pp. 56-62. doi: 10.24036/eksakta/vol19-iss1/127.

[71] Putri D, Fifendy M, putri M. DIVERSITAS BAKTERI ENDOFIT PADA DAUN MUDA DAN TUA TUMBUHAN ANDALEH (Morus macroura miq.). EKSAKTA [Internet]. 28Apr.2018 [cited 12May2019];19(1):125-30. Available

from: http://eksakta.ppj.unp.ac.id/index.php/eksakta/article/view/122

[72] Chatri, M., Mansyurdin, M., Bakhtiar, A. and Adnadi, P. (2017) "PERBANDINGAN KOMPONEN MINYAK ATSIRI ANTARA DAUN MUDA DAN DAUN DEWASA PADA HYPTIS SUAVEOLENS (L.)POIT", EKSAKTA: Berkala Ilmiah Bidang MIPA, 18(02), pp. 1-12. doi: 10.24036/eksakta/vol18-iss02/41.

[73] Azhar, M., Ahda, Y., Ihsanawati, I., Puspasari, F., Mawarni, S., Risa, B. and Natalia, D. (2017) "SKRINING BAKTERI PENDEGRADASI INULIN DARI RIZOSFER UMBI DAHLIA MENGGUNAKAN INULIN UMBI DAHLIA", EKSAKTA: Berkala Ilmiah Bidang MIPA, 18(02), pp. 13-20. doi: 10.24036/eksakta/vol18-iss02/44.

[74] Samah, S. (2017) "KARAKTERISASI PLASTIK BIODEGRADABEL DARI LDPE-g-MA DAN PATI TANDAN KOSONG SAWIT", EKSAKTA: Berkala Ilmiah Bidang MIPA, 18(02), pp. 30-38. doi: 10.24036/eksakta/vol18iss02/48.

[75] Saiya, A. (2017) "ANALISIS RESIDU KLORPIRIFOS DALAM SAYURAN KUBIS DENGAN METODE HPLC DI BEBERAPA PASAR TRADISIONAL DI SULAWESI UTARA", EKSAKTA: Berkala Ilmiah Bidang MIPA, 18(02), pp. 77-85. doi: 10.24036/eksakta/vol18-iss02/57.

[76] Amananti, W. (2017) “ANALISIS MIKROSTRUKTUR LAPISAN TIPIS TiO2:ZnO YANG DIDEPOSISIKAN DIATAS SUBTRAT KACA DENGAN METODE SPRAY COATING UNTUK DEGRADASI LIMBAH ZAT WARNA", EKSAKTA: Berkala Ilmiah Bidang MIPA, 18(02), pp. 210-215. doi: 10.24036/eksakta/vol18-iss02/81.

[77] Handayani, D. (2017) "KARAKTERISTIK CENDAWAN DARK SEPTATE ENDOPHYTE (DSE) PADA AKAR TANAMAN JAGUNG DAN PADI", EKSAKTA: Berkala Ilmiah Bidang MIPA, 18(01), pp. 61-68. doi: 10.24036/eksakta/vol18-iss01/20.

[78] Sofyanita, S. and Octaria, Z. (2018) "Fenthion Compound Degradation in the Pesticide Bayleton $500 \mathrm{ec}$ in Sonolysis, Ozonolysis and Sonozolysis with Addition of TiO2-anatase", EKSAKTA: Berkala Ilmiah Bidang MIPA, 19(2), pp. 70-79. doi: 10.24036/eksakta/vol19-iss2/153.

[79] Syafei, N. (2018) "Riset Material ANALISA FENOMENA KOROSI PELAT PIPA BAJA KARBON API 5L-X65 DALAM LARUTAN 7900 ML AIR 
LAUT DAN 100 ML AMONIAK PADA KONDISI GAS CO2 DAN H2S JENUH PADA SUHU RUANG.", EKSAKTA: Berkala Ilmiah Bidang MIPA, 19(1), pp. 7-13. doi: 10.24036/eksakta/vol19-iss1/83.

[80] Ruswandi, R. (2018) "Determination of Fructose Content resulted by Inulin Hydrolysis with DNS as Oxidizer", EKSAKTA: Berkala Ilmiah Bidang MIPA, 19(1), pp. 14-23. doi: 10.24036/eksakta/vol19-iss1/102.

[81] Advinda, L. (2018) "PERTUMBUHAN STEK HORIZONTAL BATANG JARAK PAGAR (Jatropha curcas L.) YANG DIINTRODUKSI DENGAN PSEUDOMONAD FLUORESEN", EKSAKTA: Berkala Ilmiah Bidang MIPA, 19(1), pp. 68-75. doi: 10.24036/eksakta/vol19-iss1/129.

[82] Hidayat, D. (2018) "ANALISIS RESPON PENGONTROL ON-OFF PADA KENDALI UMPAN BALIK SISTEM FISIS ELEKTRONIK”, EKSAKTA: Berkala Ilmiah Bidang MIPA, 19(1), pp. 118-124. doi: 10.24036/eksakta/vol19-iss1/119.

[83] Santoso, B. (2018) "IDENTIFIKASI AKUIFER MENGGUNAKAN METODE GEOLISTRIK RESISTIVITAS DI DAERAH BEBANDEM, KARANG ASEM, BALI", EKSAKTA: Berkala Ilmiah Bidang MIPA, 19(1), pp. 24-34. doi: 10.24036/eksakta/vol19-iss 1/101.

[84] Samah, S. (2017) "KARAKTERISASI PLASTIK BIODEGRADABEL DARI LDPE-g-MA DAN PATI TANDAN KOSONG SAWIT", EKSAKTA: Berkala Ilmiah Bidang MIPA, 18(02), pp. 30-38. doi: 10.24036/eksakta/vol18iss $02 / 48$.

[85] Sudrajat, R. (2017) "TINJAUAN TENTANG KETERKAITAN PARAMETER DENGAN MODEL REGRESI MULTIVARIAT PADA KOLAM IKAN TERTUTUP”, EKSAKTA: Berkala Ilmiah Bidang MIPA, 18(02), pp. 158-163. doi: 10.24036/eksakta/vol18-iss02/72.

[86]Tutuarima, T. (2017) "SIFAT FISIK DAN KIMIA MARMALADE JERUK KALAMANSI (Citrus microcarpa) : KAJIAN KONSENTRASI PEKTIN DAN SUKROSA Physical and Chemical Properties of Marmalade Citrus of Calamondin (Citrus microcarpa) : Study of Pectin and Sucrose Concentrations", EKSAKTA: Berkala Ilmiah Bidang MIPA, 18(02), pp. 164172. doi: 10.24036/eksakta/vol18-iss02/73.

[87] Nasir, M. (2017) "PENGARUH WAKTU HIGH ENERGY MILLING TERHADAP KARAKTERISTIK NANOKAOLIN CAPKALA ASAL KALIMANTAN BARAT", EKSAKTA: Berkala Ilmiah Bidang MIPA, 18(02), pp. 200-209. doi: 10.24036/eksakta/vol18-iss02/78.

[88] Ramli, R., Jonuarti, R. and Hartono, A. (2017) “ANALISIS STRUKTUR NANO DARI LAPISAN TIPIS COBALT FERRITE YANG DIPREPARASI DENGAN METODE SPUTTERING”, EKSAKTA: Berkala Ilmiah Bidang MIPA, 18(01), pp. 46-53. doi: 10.24036/eksakta/vol18-iss01/16.

[89] Sarjani, F., Sri Sumantyo, J. T. and Yohandri, Y. (2017) "PENGOLAHAN CITRA SATELIT ALOS PALSAR MENGGUNAKAN METODE POLARIMETRI UNTUK KLASIFIKASI LAHAN WILAYAH KOTA PADANG”, EKSAKTA: Berkala Ilmiah Bidang MIPA, 18(01), pp. 69-77. doi: 10.24036/eksakta/vol18-iss01/21.

[90] Amir, H., Akmam, A., Bavitra, B. and Azhari, M. (2017) "PENENTUAN KEDALAMAN BATUAN DASAR MENGGUNAKAN METODE GEOLISTRIK TAHANAN JENIS DENGAN MEMBANDINGKAN 
KONFIGURASI DIPOLE-DIPOLE DAN WENNER DI BUKIT APIT PUHUN KECAMATAN GUGUK PANJANG KOTA BUKITTINGGI", EKSAKTA: Berkala Ilmiah Bidang MIPA, 18(01), pp. 1930. doi: 10.24036/eksakta/vol18-iss01/13.

[91] Afandi N. APLIKASI FUZZY c-MEANS CLUSTERINGUNTUK MENGELOMPOKKAN DATA GEMPABUMI DI PROVINSI BENGKULU. EKSAKTA [Internet]. 30Nov.2017 [cited 12May2019];18(02):129-36. Available from: http://eksakta.ppj.unp.ac.id/index.php/eksakta/article/view/66

[92] Dinata M, Soehardi F. Factor Analysis of Physics Chemistry Waters that Affects Damage Safety Cliff on the Outskirts of River Siak. EKSAKTA [Internet]. 30Oct.2018 [cited 12May2019];19(2):46-9. Available from: http://eksakta.ppj.unp.ac.id/index.php/eksakta/article/view/143

[93] Harahap, F. and Lubis, L. (2018) "Analysis of Heavy Metals Distribution in the River Town of Hamasaki's Rod Padangsidimpuan”, EKSAKTA: Berkala Ilmiah Bidang MIPA, 19(2), pp. 50-56. doi: 10.24036/eksakta/vol19-iss2/149.

[94] Badrulfalah, B., Irianingsih, I. and Joebaedi, K. (2018) "Some Operations on Mixed Monotone Operator in Banach Spaces", EKSAKTA: Berkala Ilmiah Bidang MIPA, 19(2), pp. 57-61. doi: 10.24036/eksakta/vol19-iss2/150.

[95] Joebaedi, K., Parmikanti, K. and Badrulfalah, B. (2018) "First Order Space Time Autoregressive Stationary Model on Petroleum Data", EKSAKTA: Berkala Ilmiah Bidang MIPA, 19(2), pp. 62-69. doi: 10.24036/eksakta/vol19iss $2 / 152$.

[96] Vauzia, V. and Gusmira, E. (2018) "The Response of Jabon Seeds Germination (Anthocephalus cadamba (Roxb.)Miq.) against the Duration of Combustion and Illumination", EKSAKTA: Berkala Ilmiah Bidang MIPA, 19(2), pp. 80-87. doi: 10.24036/eksakta/vol19-iss2/154.

[97] Sofyanita, S. and Octaria, Z. (2018) "Fenthion Compound Degradation in the Pesticide Bayleton 500 ec in Sonolysis, Ozonolysis and Sonozolysis with Addition of TiO2-anatase", EKSAKTA: Berkala Ilmiah Bidang MIPA, 19(2), pp. 70-79. doi: 10.24036/eksakta/vol19-iss2/153.

[98]Santoso, B., Setianto, S., Hasanah, M., Wijatmoko, B., Supriyana, E. and Mohammad, H. (2018) "Mitigation of Land Movement using Self Potential Method in Ling-Anjung Region Sumedang Regency", EKSAKTA: Berkala Ilmiah Bidang MIPA, 19(2), pp. 32-39. doi: 10.24036/eksakta/vol19-iss2/141.

[99] Enjelina, W., Mansyurdin, M. and Meideliza, T. (2018) "Analysis of Nepenthes Hybrids in Bukik Taratak West Sumatra by RAPD Technique", EKSAKTA: Berkala Ilmiah Bidang MIPA, 19(2), pp. 12-20. doi: 10.24036/eksakta/vol19-iss2/137.

[100] Iskandar, I., Horiza, H. and Fauzi, N. (2017) "EFEKTIVITAS BUBUK BIJI PEPAYA (Carica Papaya Linnaeaus) SEBAGAI LARVASIDA ALAMI TERHADAP KEMATIAN LARVA AEDES AEGYPTY TAHUN 2015", EKSAKTA: Berkala Ilmiah Bidang MIPA, 18(01), pp. 12-18. doi: 10.24036/eksakta/vol18-iss01/12.

[101] Amir, H., Akmam, A., Bavitra, B. and Azhari, M. (2017) "PENENTUAN KEDALAMAN BATUAN DASAR MENGGUNAKAN METODE GEOLISTRIK TAHANAN JENIS DENGAN MEMBANDINGKAN KONFIGURASI DIPOLE-DIPOLE DAN WENNER DI BUKIT APIT PUHUN KECAMATAN GUGUK PANJANG KOTA 
BUKITTINGGI", EKSAKTA: Berkala Ilmiah Bidang MIPA, 18(01), pp. 1930. doi: 10.24036/eksakta/vol18-iss01/13.

[102] Permana, D. (2017) "MODEL STOKASTIK RANTAI MARKOV EMPAT STATUS PADA PENENTUAN NILAI HIDUP PELANGGAN”, EKSAKTA: Berkala Ilmiah Bidang MIPA, 18(01), pp. 78-85. doi: 10.24036/eksakta/vol18iss01/22.

[103]Maryudi, Maryudi, Hisyam, Anwaruddin. 2013. KINETIKA REAKSI KHROM DAN KAPUR PADAM PADA PENGOLAHAN LIMBAH PENYAMAKAN KULIT SECARA BATCH. SPEKTRUM INDUSTRI. Vol 11 , No 1

[104] Agus Wibowo, Agus Wibowo. 2010. LAJU REAKSI PENCAMPURAN MINYAK JARAK DAN AIR PADA HYDROGEN REFORMER MENGGUNAKAN PEMANAS DAN KATALIS. Prosiding Seminar Nasional Sains Dan Teknologi Fakultas Teknik. Vol 1, No 1

[105] AZIZ, SANDRA ARIFIN, GHULAMAHDI, MUNIF. 2011. Red Guava Leaf Harvesting Impact on Flavonoid Optimation in Different Growth Phases. HAYATI Journal of Bioscience. Vol 18, No 2

[106] Sukadana, I M.. 2009. SENYAWA ANTIBAKTERI GOLONGAN FLAVONOID DARI BUAH BELIMBING MANIS (Averrhoa carambola Linn.L). Journal of Chemistry. Vol. 3, No. 2

[107] Lumbessy, Mirna, Abidjulu, Jemmy, Paendong, Jessy J. E.. 2013. Uji Total Flavonoid Pada Beberapa Tanaman Obat Tradisonal Di Desa Waitina Kecamatan Mangoli Timur Kabupaten Kepulauan Sula Provinsi Maluku Utara. JURNAL MIPA UNSRAT ONLINE. Vol 2, No 1

[108] Siburian, Restauli Br, Jose, Christine, Kartika, Ganis Fia. 2015. TOTAL FENOLIK, FLAVONOID, DAN AKTIVITAS ANTIOKSIDAN PRODUK TEH HIJAU DAN TEH HITAM TANAMAN BANGUN-BANGUN (Coleus amboinicus) DENGAN PERLAKUAN ETT REMPAH-REMPAH. Jurnal Online Mahasiswa (JOM) Bidang Matematika dan Ilmu Pengetahuan Alam. Vol 2, No 1

[109] Ridwan Rais, Ichwan. 2015. ISOLASI DAN PENENTUAN KADAR FLAVONOID EKSTRAK ETANOLIK HERBA SAMBILOTO (Andrographis paniculata (BURM.F.) NESS). PHARMACIANA. Vol 5, No 1.

[110] Ekowati, Juni. 2010. Pengaruh Katalis pada Sintesis Asam OMetoksisinamat dengan Material Awal O-Metoksi Benzaldehida dan Uji Aktivitas Analgesiknya. Majalah Farmasi Airlangga. Vol 8, No 2

[111] Ariyani, Farida, Murtini, Jovita Tri, Hermana, Irma. 2012 . Pemanfaatan Ekstrak Air Daun Jambu Biji Sebagai Antioksidan Alami Pada Pengolahan Patin Asin. Jurnal Pascapanen dan Bioteknologi Kelautan dan Perikanan. Vol 7, No 1

[112] Isnaeni, . Sugiyartono, ., Kusumawati, Idha, Rijal, Muh. Agus Syamsur. 2016. Efek Imunomodulator Kombinasi Susu Probiotik dan Ekstrak Daun Jambu Biji. JFIOnline. Vol 8, No 1

[113] Muharni, Septi, Martini, Rose Dinda. 2013. Efek Penggunaan Suplemen Ekstrak Daun Jambu Biji (Psidium guajava Linn.) dan Angkak (Monascus purpureus) dalam Meningkatkan Trombosit pada Demam Berdarah Dengue 
(DBD) di Instalasi Rawat Inap Ilmu Penyakit Dalam RSUP. DR. M. Djamil Padang. Jurnal Penelitian Farmasi Indonesia. Vol 1, No 2

[114] Maharani, -, Rosalina, Purwaningsih, Puji. 2013. PENGARUH PEMBERIAN AIR REBUSAN DAUN JAMBU BIJI ( PSIDIUM GUAJAVA) TERHADAP KADAR GLUKOSA DARAH PADA PENDERITA DIABETES MELLITUS TIPE II DI DESA LEYANGAN KECAMATAN UNGARAN TIMUR KABUPATEN SEMARANG. Vol 1, No 2

[115] Alfian Noor. 1998. Kemungkinan Penggunaan Poliprenol untuk Taksonomi Kimia Tanaman. HAYATI Journal of Biosciences. Vol 5, No 3

[116] Ningrum, Naliawati Prastiya Indra Kusuma, Muhamad Alfin Rokhati, Nur. 2013. PEMANFAATAN MINYAK GORENG BEKAS DAN ABU KULIT BUAH KAPUK RANDU (SODA QIE) SEBAGAI BAHAN PEMBUATAN SABUN MANDI ORGANIK BERBASIS TEKNOLOGI RAMAH LINGKUNGAN. JURNAL TEKNOLOGI KIMIA DAN INDUSTRI. Volume 2. Nomor 2.

[117] Winardiantika, Dody Kastono, Sri Trisnowati, Venti. 2012. Pengaruh Waktu Pangkas Pucuk dan Frekuensi Pemberian Paklobutrazol terhadap Pertumbuhan dan embungaan Tanaman Kembang Kertas (Zinnia elegans Jacq.). Jurnal Budidaya Pertanian. Vol.1. No 2.

[118] Nur Shinta Febriani, Didik Indradewa, dan Sriyanto Waluyo, Dwi. 2012. Pengaruh Pemotongan Akar dan Lama Aerasi Media Terhadap Pertumbuhan Selada (Lactuca sativa L.) Nutrient Film Technique. Jurnal Budidaya Pertanian. Vol. 1. No 1.

[119] Rustiani, Ummu Salamah Endah, Ariningsih Salji Nurjanah, Nurjanah Prasetiawan, AndiNurmaida, Nurmaida. 2015. Deteksi Bakteri Penyebab CVPD pada Jeruk Menggunakan DNA Asal Tulang Daun. Jurnal Fitopatologi Indonesia. Vol. 11. No 3.

[120] Juwairiah, Juwairiah . 2016. Meningkatkan Pembelajaran IPA-Kimia Pada Materi Pokok Reaksi Kimia Melalui Metode Praktikum Berbasis Bahan Alam. Jurnal Visipena. Vol 7, No 1

[121] Yulianti, Rika. 2015. Uji In Vitro dan In Vivo Gel Kombinasi Ekstrak Daun Sirsak (Annona muricata, L) dan Ekstrak Daun Jambu Biji (Psidium guajava, L) Sebagai Obat Anti Jerawat. JFIOnline. Vol 7, No 3

[122] Luo, Dehan, Shao, Yawen. 2013. Discrimination of Chinese Herbal Medicine by Machine OlfactionTELKOMNIKA Indonesian Journal of Electrical Engineering. Vol 11, No 2

[123] Maksum Radji . 2005. PERANAN BIOTEKNOLOGI DAN MIKROBA ENDOFIT DALAM PENGEMBANGAN OBAT HERBAL. Majalah Ilmu Kefarmasian.vol.2.no.3

[124] Ngestiningsih, Dwi. Hadi, Suyanto. 2011 . Ekstrak Herbal (Daun Salam, Jintan Hitam, Daun Seledri) dan Kadar IL-6 Plasma Penderita Hiperurisemia. MEDIA MEDIKA INDONESIANA.Vol.45 No.2

[125] Cahyo Kumoro, Andri, Hasan, Masitah. 2008 . EXTRACTION OF HERBAL COMPONENTS â THE CASE FOR SUPERCRITICAL FLUID EXTRACTION. TEKNIK. Volume 29, Nomor 3

[126] Jasaputra, Diana Krisanti. 2011. Herbal Medicine for Obesity. Jurnal Medika Planta. Vol 1, No 3 
[127] Erawati Dewi, Luh Joni.2009. PENGEMBANGAN MEDIA PEMBELAJARAN REAKSI KESETIMBANGAN KIMIA. JPTK. Vol. 6. No.2.

[128] Mukaromah, Ana Hidayati, Irawan, Bagus. 2008. Pemanfaatan Reaktor Membran Fotokatalitik dalam Mendegradasi Fenol dengan Katalisis TiO2 dengan Adanya Ion Logam $\mathrm{Fe}(I I I)$ dan $\mathrm{Cu}(\mathrm{II})$. PROSIDING SEMINAR NASIONAL. Vol. 1. No.1.

[129] Yusnitati, Yusnitati. 2006. EFEKTIVITAS PENAMBAHAN NIKEL PADA PENCAIRAN BATUBARA PERINGKAT RENDAH MENGGUNAKAN KATALIS ALAMI LIMONIT. Jurnal Energi dan Lingkungan (Enerlink). Vol. 2. No.1.

[130] Al Hakimi, Nurush Shofi, Hanapi, Ahmand, Fasya, Ahmad Ghanaim. 2017. Green Synthesis Senyawa Imina dari Vanillin and Anilina dengan Katalis Alami Air Jeruk Nipis (Citrus aurantifolia). ALCHEMY Journal of Chemistry. Vol. 5.No.4.

[131] Hartiniati,Hartiniati.2008. Evaluasi Reaktifitas Katalis Nimo Dalam Proses Pencairan Batubara Banko Selatan Dan Australian Loy Yang. Jurnal Energi Dan Lingkungan (Enerlink). Vol.4 No. 1

[132] Firdausy, Kartika, Yudhana, Anton, Sugianto, Ikhsan. 2006. Visualisasi Metode Refleksologi Untuk Penyembuhan Penyakit Dengan Visual Basic. Vol.4 No.1

[133] Wiralis, Wiralis, Purwaningsih, Endang. 2009. Pengaruh Pemberian Jus Jambu Biji (Psidium Guajava L) Terhadap Volume Kaki dan Kadar Ion Nitrit Adjuvant Induced Arthritis Tikus Wistar. Vol. 43 No.4

[134] Rukmiasih, PS, Hardjosworo, PP, Kataren, PR, Matitaputty. 2010. Penggunaan beluntas, vitamin $\mathrm{C}$ dan E sebagai antioksidan untuk menurunkan off-odor $(25 \%)$ daging itik alabio dan Citaheup. Jurnal Ilmu Pertanian Indonesia. Vol.15 No.2

[135] Upik Kesumawati Hadi, Susi Soviana, Dwi Djayanti Gunandini. 2012. Aktivitas nokturnal vektor demam berdarah dengue di beberapa daerah di Indonesia. Jurnal Entomologi Indonesia. Vol.9 No.1

[136] Hartawan, Risza,Dharmayanti, Ni Luh Putu Indi, Robinson, Karl, Mahony, Timothy, Meers,Joanne. 2012. Expression Of Two N1 Clones With Single Amino Acid Dissimilarity Of Avian Influenza H5n1 Virus. Hayati Journal Of Biosciences. Vol.19 No.4

[137] Gunawan Giu, La Ode Muh., Ramli, Muhammad, Alirman Afu, La Ode. 2017. Perbandingan Daya Tahan Tubuh Ikan Ternate Chromis (Chromis Ternatensis) Dan Common Goby (Bathygobius Fuscus) Terhadap Kenaikan Suhu Pada Wadah Terkontrol. Jurnal Sapa Laut (Jurnal Ilmu Kelautan). Vol.2 No.1

[138] Amurwaningsih, Musri, Arum Darjono, Uswatun Nisa. 2010. Analisis Hubungan Kualitas Hidup Yang Berhubungan Dengan Kesehatan Mulut (OHRQoL) Dan Status Kecemasan Dengan Status Nutrisi Pada Masyarakat Usia Lanjut. Majalah Ilmiah Sultan Agung. Vol.48 No.123

[139] Effendi, Adi Teruna, Sediono, M, Suksmono, HS, Erwanto, B, Effendi, Yekti Hartati, Dewi, Mira, Karyadi, Darwin. 2010. Efektivitas Pemberian Cgf 40\% Dalam Mempercepat Peningkatan Trombosit Pada Penderita Demam Berdarah Dengue. Jurnal Gizi dan Pangan. Vol.5 No.3 
[140] Damayanthi, Evy, Kustiyah, Lilik, Khalid, Mahani, Farizal, Henry.2010. Aktivitas Antioksidan Bekatul Lebih Tinggi Daripada Jus Tomat Dan Penurunan Aktivitas Antioksidan Serum Setelah Intervensi Minuman Kaya Antioksidan. Jurnal gizi dan pangan. Vol.5 No.3

[141] Nunung D. Putra, Khaswar Syamsu, Ani Suryani,2004. KAJIAN PENGARUH KONSENTRASI H2SO4 DAN SUHU REAKSI PADA PROSES PRODUKSI SURFAKTAN METIL ESTER SULFONAT (MES) DENGAN METODE SULFONASI.VOL 14,NO 2

[142] al Hakimi, Nurush Shofi, Hanapi, Ahmand, Fasya, Ahmad Ghanaim,2017.Green Synthesis Senyawa Imina dari Vanillin and Anilina dengan Katalis Alami Air Jeruk Nipis (Citrus aurantifolia). Vol 5, No 4

[143] Abdullah, Jaya, Jaka Darma, Rodiansono,2010. Optimasi Jumlah Katalis $\mathrm{KOH}$ dan $\mathrm{NaOH}$ pada Pembuatan Biodiesel dari Minyak Kelapa Sawit Menggunakan Kopelarut. Vol 4, No 1

[144] Mambang, D. Elysa Putri, Rosidah, -, Suryanto, Dwi,2014. AKTIVITAS ANTIBAKTERI EKSTRAK TEMPE TERHADAP BAKTERI Bacillus subtilis DAN Staphylococcus aureus [Antibacterial Activity of Tempe Extracts on Bacillus subtilis and Staphylococcus aureus]. Vol 25, No 1

[145] S, Gunanati, Priosoeryanto,Bambang Pontjo, Wientarsih, Ietje, Sumarny, Ros,2009. Pengobatan penyakit tumor mammae melalaui operasi (matektomi dan ovariohisterektomi) dan kombinasinya (tanaman herbal) pada hewan. Vol 14, No 1

[146] Christiono, Sandy. 2012, "Efektivitas Resin Bis-Gma Sebagai Bahan Fissure Sealant Pada Perubahan Suhu Dalam Mengurangi Kebocoran Tepi (Penelitian Eksperimental Laboratoris)". Majalah Ilmiah Sultan Agung. Vol 49, No 124

[147] Arifin, Bustanul. 2013. 'Aplikasi Sensor Passive Infrared (Pir) Untuk Pendeteksian Makhluk Hidup Dalam Ruang”. Prosiding Seminar Nasional Sains Dan Teknologi Fakultas Teknik. Vol 1, No 1

[148] Refinel. Zaharasmi, Tetra, Olly Norita. 2015. Kinetika Dan Selektifitas Sistim Transpor Cu (Ii) Antar Fasa Melalui Teknik Membran Cair Fasa Ruah Dengan Menggunakan Oksin Sebagai Zat Pembawa. Jurnal Riset Kimia, Vol 4, No 1

[149] Tasim, Lina, Santoso, I R. S., Rombang, W A. R..2013.Analisis Pemahaman Konsep Reaksi Kimia Melalui Pendekatan Pembelajaran Langsung Pada Siswa SMP Negeri 13 Tidore Kepulauan Vol 1, No 3

[150] Desy Kurniawati, Intan Lestari, Harmiwati, Salmariza Sy, Zulkarnain Chaidir, Edison Munaf, Rahmiana Zein, Hermansyah Aziz and Rahadian Zainul.2015. Biosorption of $\mathrm{Pb}$ (II) from aqueous solutions using column method by lengkeng (Euphoria logan lour) seed and shell.Vol 7 no 12 